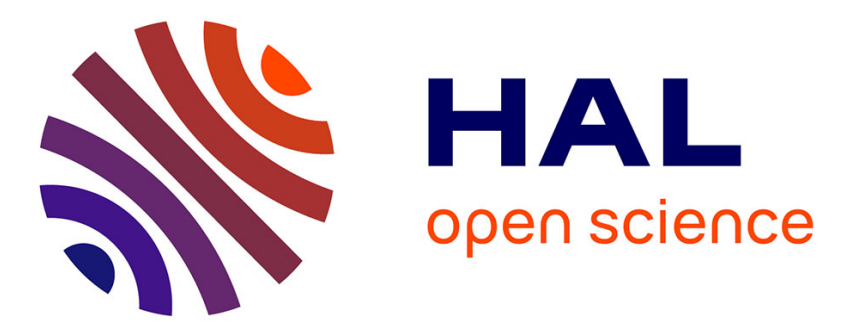

\title{
Land characterisation for soil-based constructed wetlands: Adapting investigation methods to design objectives
}

A. Petitjean, N. Forquet, J.M. Choubert, Marina Coquery, M. Bouyer, Catherine Boutin

\section{To cite this version:}

A. Petitjean, N. Forquet, J.M. Choubert, Marina Coquery, M. Bouyer, et al.. Land characterisation for soil-based constructed wetlands: Adapting investigation methods to design objectives. Water Practice and Technology, 2015, 10 (4), pp.660-668. 10.2166/wpt.2015.078 . hal-01355934

\section{HAL Id: hal-01355934 \\ https://hal.science/hal-01355934}

Submitted on 24 Aug 2016

HAL is a multi-disciplinary open access archive for the deposit and dissemination of scientific research documents, whether they are published or not. The documents may come from teaching and research institutions in France or abroad, or from public or private research centers.
L'archive ouverte pluridisciplinaire HAL, est destinée au dépôt et à la diffusion de documents scientifiques de niveau recherche, publiés ou non, émanant des établissements d'enseignement et de recherche français ou étrangers, des laboratoires publics ou privés. 
Petitjean, A., Forquet, N., Choubert, J.-M., Coquery, M., Bouyer, M., Boutin, C. (2015). Land characterisation for soil-based constructed wetlands: adapting investigation methods to design objectives. Water Practice \& Technology, 10(4), 660-666.

\title{
LAND CHARACTERISATION FOR SOIL-BASED CONSTRUCTED WETLANDS: ADAPTING INVESTIGATION METHODS TO DESIGN OBJECTIVES.
}

\author{
Petitjean, $\mathrm{A}^{\mathrm{a}}$, Forquet, $\mathrm{N}^{\mathrm{a}}$, Choubert, J-M $\mathrm{M}^{\mathrm{a}}$, Coquery, $\mathrm{M}^{\mathrm{a}}$, Bouyer, $\mathrm{M}^{\mathrm{b}}$, Boutin, $\mathrm{C}^{\mathrm{a}}$

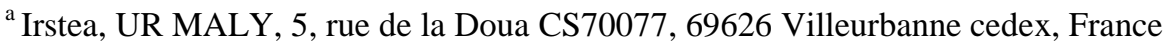 \\ nicolas.forquet@irstea.fr \\ ${ }^{\mathrm{b}}$ Bordeaux Métropole. Esplanade Charles-de-Gaulle 33076 Bordeaux Cedex
}

\begin{abstract}
Buffer zones between wastewater treatment plants and receiving water bodies have recently gained interest in France. These soil-based constructed wetland (SBCW) systems receive treated wastewater and may have various designs aiming to mimic "natural" wetlands. Research is needed to assess the treatment efficiency of such systems. To this aim, a comprehensive study is carried out to understand the fate of water, conventional pollutants (suspended solids, organic carbon, ammonium, and phosphates), micro-pollutants that are refractory to up-stream biological treatment, and pathogens. Special attention must be paid to understand the fate of the infiltrated treated wastewater in the field where systems are built, in order to ensure their long-term operation and to protect the underground water bodies. To address these issues, we propose a comprehensive strategy combining successive steps using either geological or hydrological methods. It provides the following prominent information for a proper design of SBCW: (1) the number and the location of the different soil layers; (2) the infiltration capacity of each layer; (3) the water table depth. The paper presents a successful application of the proposed strategy to evaluate the fate of the infiltrated treated wastewater before the implementation of a semi-industrial scale SBCW in Bègles (France). Moreover, methods used for long-term efficiency assessment are introduced.
\end{abstract}

Keywords

Pollutant removal; soil-based systems; hydrogeology; infiltration.

\section{INTRODUCTION}

\section{Soil-based constructed wetlands (SBCWs) receiving treated wastewater: scope and aims.}

SBCWs are systems located between wastewater treatment plants (WWTP) and receiving water bodies. The literature on these systems is quite abundant on their ability to enhance the water quality for major pollutants, pathogens (Ayaz, 2009 and Tzanakakis et al., 2009) and micropollutants (Li et al., 2014; Verlicchi and Zambello, 2014). They have also recently gained an increased interest from wastewater treatment companies and stakeholders (Pagotto et al., 2014, Blin et al., 2014 and Kampf et al., 2007).

SBCWs aim at protecting receiving water bodies, especially at minimum river flow periods. Indeed, according to the literature, SBCWs: (1) can be considered as buffer zones; (2) allow infiltration (decrease in discharged treated wastewater); (3) potentially improve the treated wastewater quality. Besides, the potential enhancement of biodiversity aspects seduces designers and contracting 
authorities, and partly explains the large development of SBCWs (in France, more than 500 SBCWs have been built, most of them in the last 5 years, Prost-Boucle and Boutin, 2013).

A previous study on French SBCWs (Prost-Boucle and Boutin, 2013) showed no clear link between their design and aims. Moreover, the sizing of these systems is not established and almost always corresponds to the remaining space available after the WWTP has been built. Hence, more research is needed to assess the efficiency of SBCWs as regards to their assigned objectives and to establish design and sizing methods.

\section{SBCWs: processes}

SBCWs receive effluents of variable quality depending on the treatment performed upstream (effluent from primary, secondary or tertiary treatment) as influent. Water parameters regarding pollutants will evolve throughout the SBCWs depending on the different processes occurring. Pollutant removal takes place in one or several of the three components of SBCWs: (1) free water; (2) soil; (3) plants. Regarding SBCWs, the infiltration of treated wastewater is one of the main goals. Thus, soil is supposed to be the compartment where most of the treatment occurs. However, infiltration of treated wastewater may also change soil mechanical and chemical characteristics.

Water flow in variably saturated soil. Water flow in soils is controlled by (1) porous media initial conditions (e.g., water content and temperature); (2) boundary conditions (inflow i.e. loading rate, and outflow - water table level), and (3) soils intrinsic hydrodynamic characteristics (e.g., pore size distribution, pore connectivity, matrix hydrophobicity). Unlike the hydraulic loading rates that can be controlled, water table level and rainfalls vary according to seasons, thus influencing the effective infiltration capacity.

Filtration. Large influent particles are filtered at the filter surface, whereas small particles (e.g., colloids) may migrate within soils and sometimes be adsorbed to the solid matrix (Keller and Auset, 2007).

Biological activity. Nutrients transported in the soil water phase due to treated wastewater loading promote growth of attached microorganisms (Thullner, 2010). The biomass activity can be aerobic, anoxic or anaerobic. The biomass is responsible for degradation of macro-pollutants and of some micro-pollutants. However, the resulting biofilm build-up can reduce soil permeability.

Adsorption-desorption. Adsorption and desorption processes are ruled by equilibrium laws between solid and liquid concentrations of the pollutants. These laws also largely depend on physicochemical parameters (e.g., matrix adsorption sites, temperature, redox, $\mathrm{pH}$, chemical species characteristics).

The strong interplay between the aforementioned processes is obvious, and combinations of them lead to an increase or decrease in subsurface water quality. Two main characteristics define an efficient and sustainable SBCW: its ability to maintain the infiltration capacity and to enhance the influent quality. That said, two main phenomena could affect SBCWs operation: clogging and pollutants leaching.

Clogging matter (or biomat, Gette-Bouvarot et al., 2013) is the result of particle filtration and biological activity. The biomat formation leads to an increase in pore-water quality and to a decrease in soil infiltration capacity. It needs to be controlled to avoid clogging issues. Indeed, attached growth treatment systems like soil treatment units cannot be seen as systems undergoing stationary phenomena. These systems constantly evolve, and a proper kind of design and/or operation can lead to a resilient balance between pro and con effects of clogging, while illconsidered kinds may accelerate critical clogging.

Leaching is due to pollutants desorption from the soil matrix and can create a decrease in underground water quality. It can apply to adsorbed pollutants coming from the influent, as well as to pollutants coming from the soil matrix (most of them metal ions in natural soils). It is due to a change in the adsorption-desorption equilibrium, caused either by a change in redox or $\mathrm{pH}$ 
condition (e.g. due to bacterial activity), hydrolysis of organic matter, or an excess in water flow (Ollivier et al., 2013).

\section{Problematic}

Soil is often considered as an efficient medium for wastewater remediation when using low hydraulic loading rates (fractions of the saturated hydraulic conductivity, Siegrist, 2014). However, the sustainability of systems operated at higher loading rates remains uncertain. Systems using undisturbed soil for wastewater treatment are rather simple and cheap to build, but involve a large variety of interconnected processes. This makes soil-based systems a challenge for researchers.

In this paper, the authors propose an overview of available methods for the study of SBCWs: (1) studies required for design and building; (2) the choice of a comprehensive set of methods to be applied for their long term (3-4 years) study. These methods are presented thereafter, then classified and discussed. An original strategy is then proposed.

\section{SBCWs PRE-IMPLEMENTATION STUDIES}

\section{Required information for SBCWs design and construction}

Figure 1 shows the main hydro-geophysical information needed before building a SBCW.

The first soil layers depth (and its spatial variation inside the chosen plot) needs to be determined, until reaching either a highly impermeable soil layer or the permanent (independent on seasons) water table. This can be proceeded through piezometers installation (and subsequent transient water table evaluation) and infiltration capacity tests. If an impermeable soil layer is found, the receiving water body has to be identified (e.g. a watercourse nearby the plot).
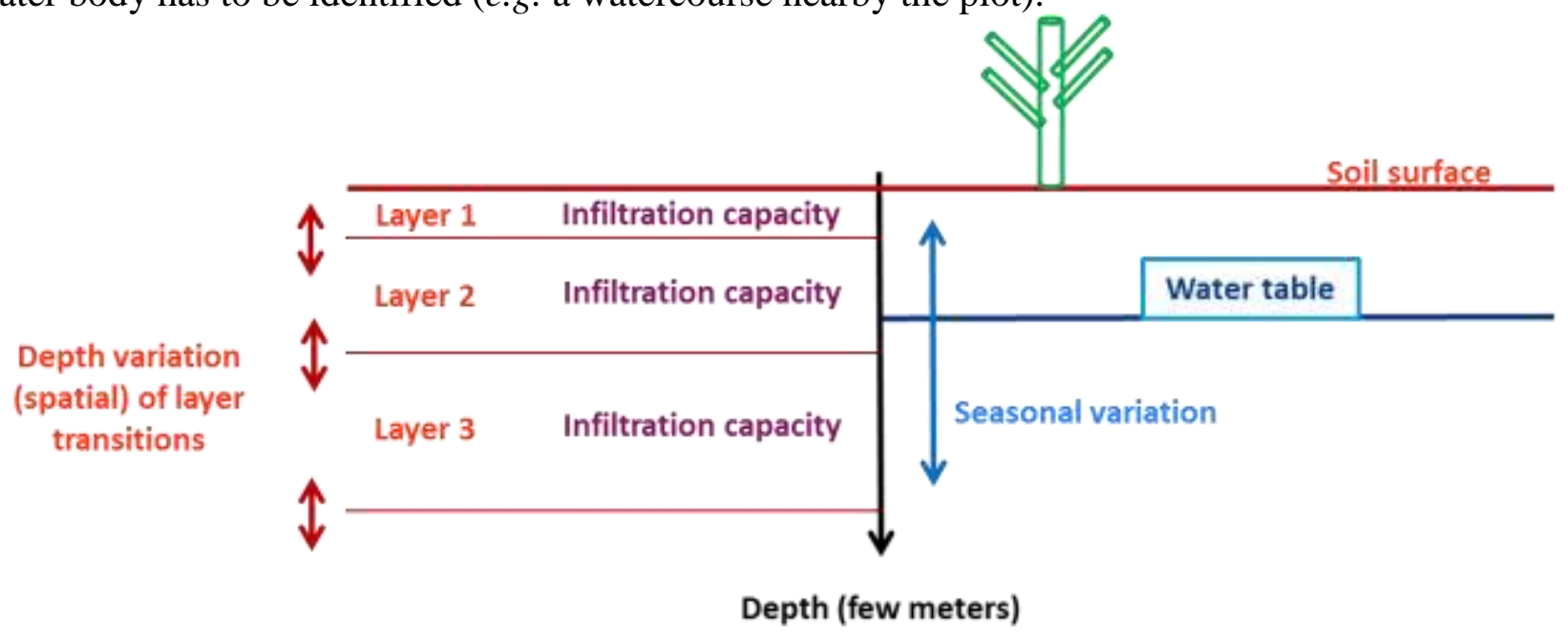

Figure 1. Schematic presentation of required information for SBCWs building: soil layers levels, infiltration capacity and water table level in vadose zone.

\section{Material and methods}

Methods detailed in this chapter were applied in Clos de Hilde WWTP, located in Bègles (33, France) near Bordeaux before the building of a set of semi-industrial scale SBCW pilots.

Identifying vadose zone soil structure has become significantly easier with the development of geophysical methods. Using these "non-invasive" methods, the screening of the studied zone is less time consuming than traditional auger investigations. However geophysical signals do not only depends on the structure and the texture of the soil layers. It is therefore necessary to perform auger tests to identify precisely the nature of the soil layers and also decipher interactions (like biochemical reactions). Three geophysical methods were tested in association with auger tests: (1) Electrical Resistivity Tomography (ERT), (2) controlled-source electromagnetic induction method (EM) and (3) Ground-Penetrating Radar (GPR). 
Auger test (figure 2.a) is a spot measurement that can be mechanical or manual. It gives access to the depth of the first soil layers and their textures.

ERT involves the measurement of a set of apparent resistivities, and the post-processing of these data allows the determination of a probable spatial-distribution of the resistive characteristics of soil. Soil electrical resistivity depends on lithology, pore fluid chemistry and water content (Binley and Kemna, 2005) and therefore provides interesting information for both site description and the monitoring of transient phenomena (e.g., variation of pore fluid phenomena or water content).

EM measures the electrical conductivity averaged over a volume of soil. Both methods are complementary. EM allows performing measurements over larger areas but vertical variations in soil electrical conductivity are averaged. ERT can only be carried out on smaller areas but provides vertical cross-sections of the soil electrical resistivity.

GPR uses radar pulses to image the subsurface in a nondestructive way. The method uses electromagnetic radiation in the microwave band of the radio spectrum, and detects the reflected signals from subsurface structures/layers due to a spatial change in the soil dielectric constant. It permits high resolution data acquisition (about $5 \mathrm{~cm}$ in depth) between 0 and $1.5 \mathrm{~m}$ depth.

Constant head infiltrometry method (NF EN ISO 22282-5, AFNOR, 2014) is a spot measurement that was used to determine the effective clear water infiltration capacity of soil layers.

$5 \mathrm{~m}$ depth piezometers (following the French standard NF P94-157-2, AFNOR, 1996) were installed at the borders of the plot. They were equipped with in line water level monitoring systems (STS DL/N) in order to follow the water table seasonal variation.

Soil samples were analyzed for $\mathrm{Li}, \mathrm{Mn}, \mathrm{As}, \mathrm{Cd}, \mathrm{U}, \mathrm{B}, \mathrm{Fe}, \mathrm{Se}, \mathrm{Sn}, \mathrm{Al}, \mathrm{Co}, \mathrm{Rb}, \mathrm{Sb}, \mathrm{Ti}, \mathrm{Ni}, \mathrm{Sr}, \mathrm{Ba}, \mathrm{V}$, $\mathrm{Cu}, \mathrm{Tl}, \mathrm{Hg}, \mathrm{Cr}, \mathrm{Zn}, \mathrm{Ag}$ and $\mathrm{Pb}$ using Inductively Coupled Plasma Mass Spectrometry (ICP-MS). Soil samples were also analyzed for hydrophobic organic substances (ex. polycyclic aromatic carbons, alkylphenols, polybrominated diphenyl ethers, polybrominated biphenyls ...) by GC-MSMS or LC-MS-MS.

a.

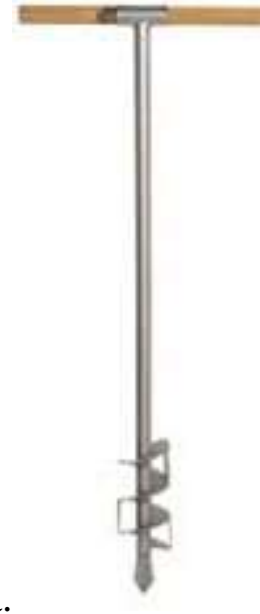

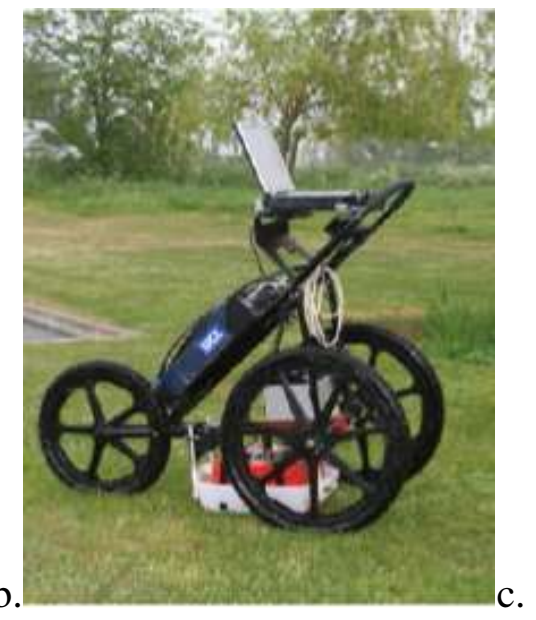

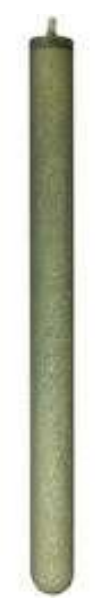

d.

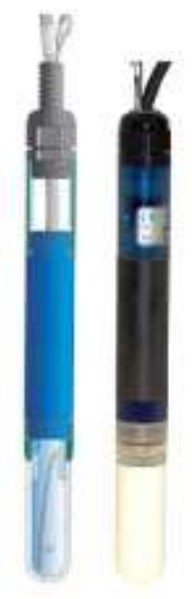

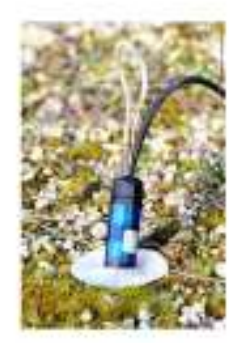

Figure 2. Material for soil characterization: a. manual auger (1m length); b. radar analysis device GPR GSSI SIR-20; c. Porous cups (UMS SiC40, $4 \mathrm{~cm}$ diameter and $40 \mathrm{~cm}$ length); d. tensiometer (UMS T8); e. FDR (Campbell sci. CS616). 


\section{Results}

Figure 3 displays an example of interpreted GPR data for a $37 \mathrm{~m}$ section of the site. Colors (unitless) embody subsurface wave reflection due for instance to a change in soils layers or a massive stone: stronger reflections are represented in red while smaller are in blue. These data (like also ERT and EM profiles, not shown) needed to be combined to auger test results to deduce texture profiles of the plot. Repeated 2D profile acquisition lead to a 3D display of the plot subsurface (not shown). Then, infiltration capacity tests were implemented in the identified layers. The method presented here used tap water and gave the upper bound of the soil layer infiltration capacity.

Figure 3 shows that two main soil layers could be found in the plot section: the first one is a backfill layer with a maximal $50 \mathrm{~mm} / \mathrm{h}$ infiltration capacity, and the second one is a homogeneous clay layer with $2 \mathrm{~mm} / \mathrm{h}$ infiltration capacity. In the case of high hydraulic loading rates (like in SBCW systems operation), this proved that most of the water flow will happen in the backfill layer. The water will be guided by gravity to lower heights parts of the backfill-clay interface.

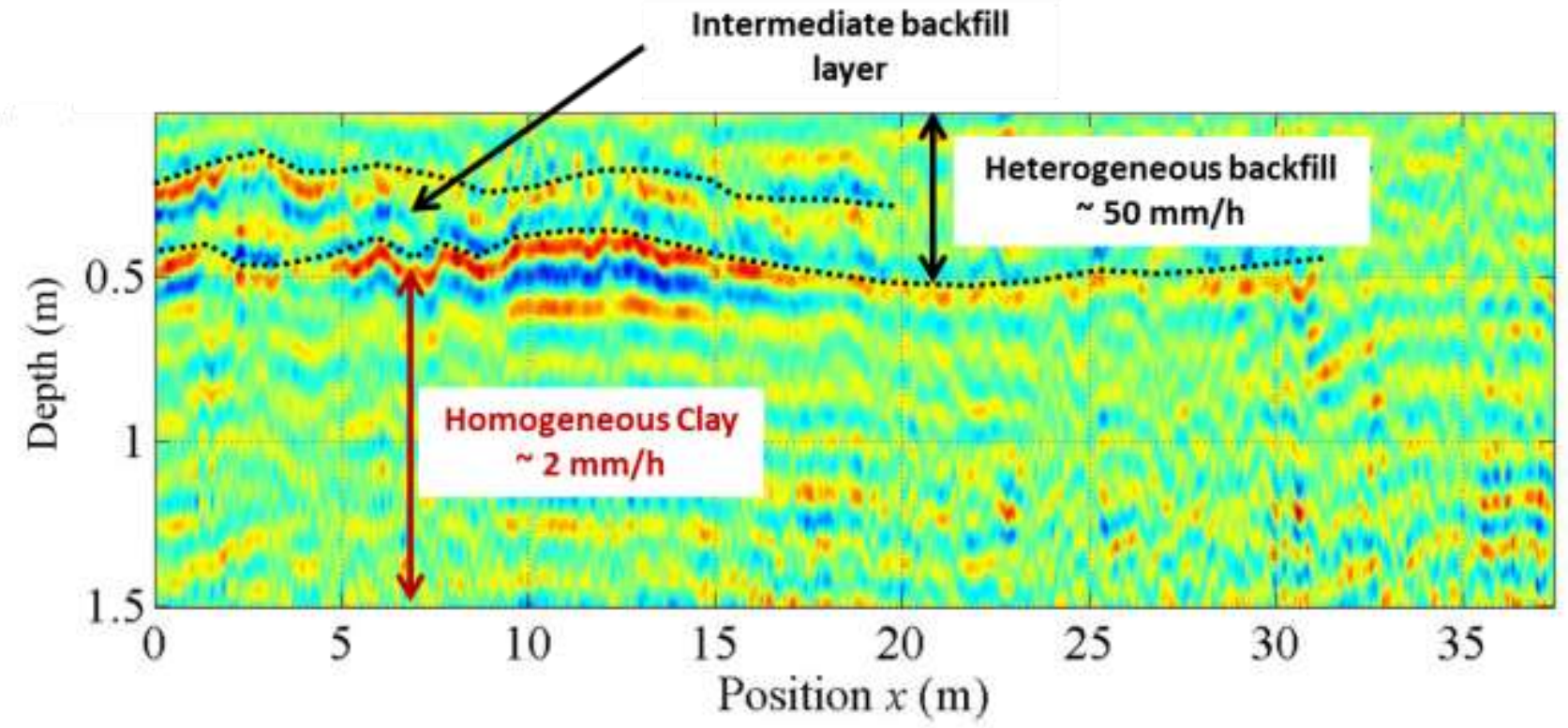

Figure 3. Example of 2D soil profile from radar data acquisition in, Bègles (33). Red colors (no unit) mean high reflections inside the soil (for instance stones or soil layers interfaces) while green colors mean low reflections.

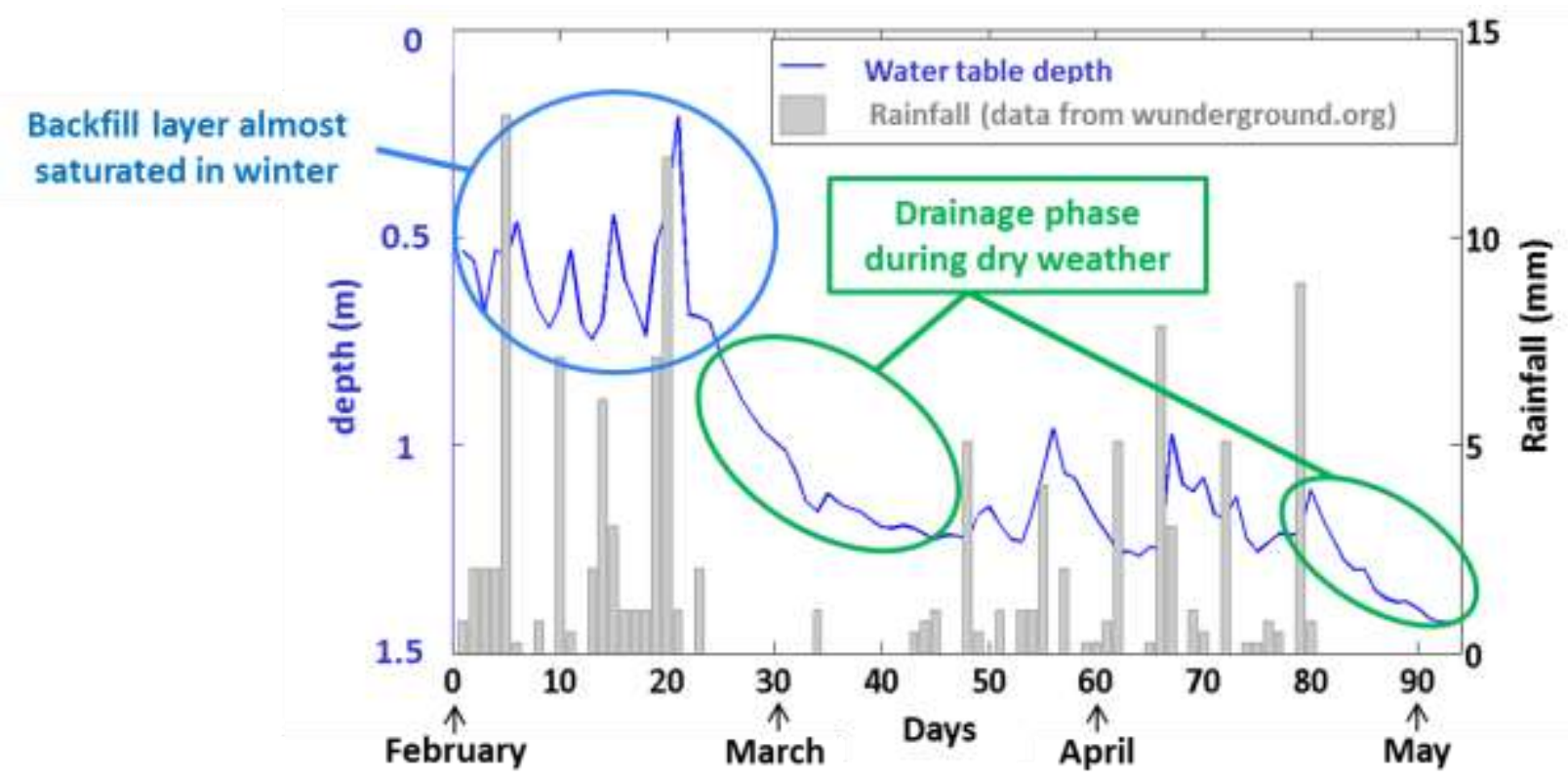

Figure 4. Water table depth and rainfall versus time (Bègles (33) in 2013). 
Figure 4 displays the water table depth and rainfalls as a function of time. The main information determined here is the seasonal variation of the water table depth, and the impact of rainfalls on it. Indeed, in 2013, the water table was $0.7 \mathrm{~m}$ (mean values), higher in winter than in springtime. However, water table depth peaks seemed to be driven by stronger daily rainfalls. These facts underlined the relatively low overall plot infiltration capacity (due to the impermeable subsurface clay layer) and the seasonal variation in the hydrodynamics boundary conditions: the effective plot infiltration capacity will be lower in winter than in summer. We also verified that the water table was not influenced by periodic tides.

\section{SBCWs LONG TERM ASSESSMENT}

The methods detailed in this section should be implemented for the assessment of SBCW. They will be applied for the set of semi-industrial scale soil-based SBCW pilots in Bègles (33, France). Both meadow and ditch kind of SBCWs are currently being built nearby the Clos de Hilde WWTP. Figure 5 gives a sketch of a ditch and the equipment used for in-line hydraulics and subsurface water quality monitoring. SBCWs soil component potential pollutants remediation will be tested. The monitoring scheme has also been designed in order to have an insight into the main phenomena that create concern about soil-based SBCWs operation: clogging and pollutants leaching.

Clogging and pollutant removal/leaching are impacted by water flow processes. Thus, two kinds of hydrodynamic parameters in variably saturated conditions will be monitored: (1) water content and (2) water pressure.

Water content measurements will be given by Frequency Domain Reflectometry (FDR) devices (figure 2.e, Campbell CS616), and water pressure by tensiometers (figure 2.d, UMS T8).

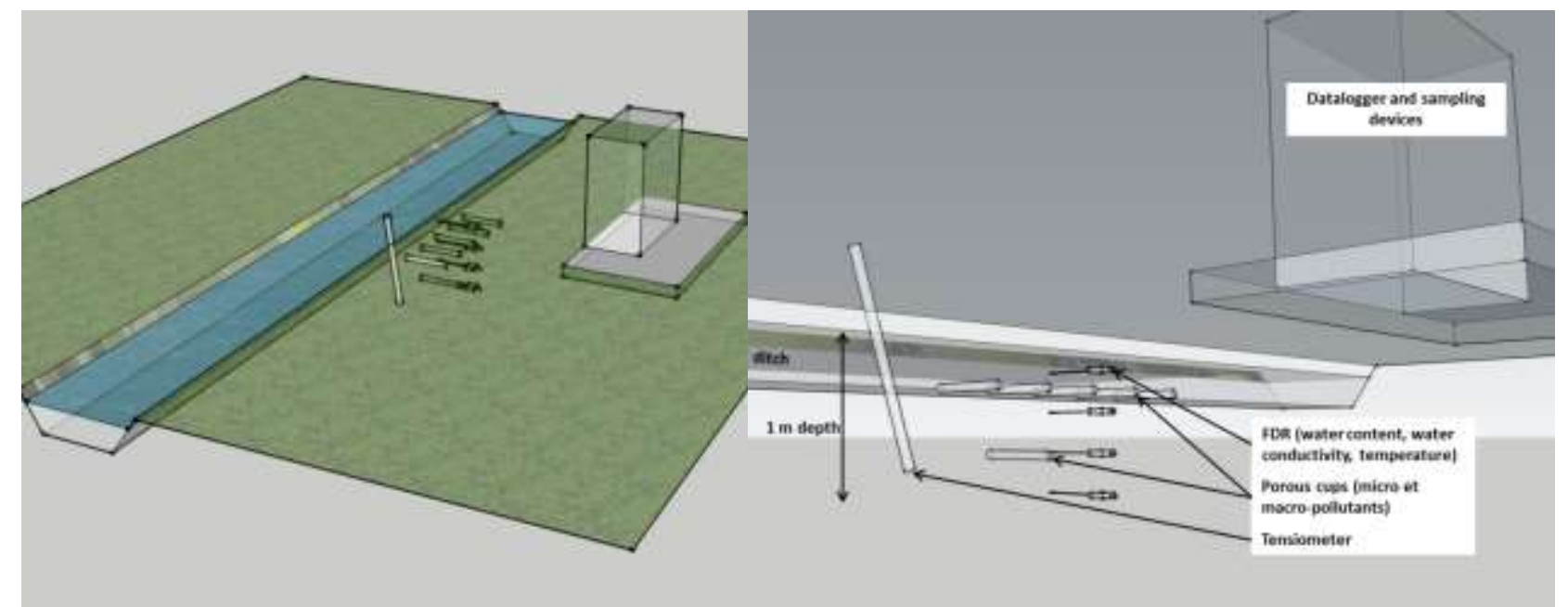

Figure 5. Sketch of a ditch (portion), on the left; detailed equipment on the right.

\section{Evaluation of the infiltration dynamics}

Methods aiming at evaluating clogging will be run at the SBCW scale.

Tracer tests with potassium bromide injection and ERT monitoring have been chosen as a nondestructive method for the infiltration dynamics assessment in ditch systems. The method allows acquiring a 3D image of the infiltration bulb at different time steps. The tracer tests will be performed at the very beginning of the SBCW operation and every 6 months throughout the project monitoring duration (4 years). As wastewater infiltration creates biomat, the infiltration bulb should grow more slowly as a consequence of a decrease in soil infiltration capacity (indirect clogging assessment).

At the same time and period, direct measurement of infiltration capacity (NF EN ISO 22282-5, AFNOR, 2014) on SBCWs surface will be done. The main advantage of using ERT is assumed to be the capacity of localizing the clogged zone and estimating its extent. 


\section{Pollutants remediation and leaching}

Three methods will be used to assess soil pollutants leaching: (1) soil chemical analysis, (2) subsurface water sampling and chemical analysis and (3) piezometers water chemical analysis.

Soil chemical analysis (trace pollutants) has been used for the SBCWs pre-implementation study, and will be run from time to time inside SBCWs during their long-term assessment (SBCW scale). Silicon carbide (SiC) porous cups (figure 2.c) will be used to sample subsurface water inside SBCWs (figure 5). Both major and trace pollutants will be analyzed (SBCW scale).

Water from piezometers installed at the borders of the SBCWs site will also be analyzed in order to assess a potential broader pollutants contamination (site scale).

\section{DISCUSSION}

Table 1 summarizes the methods, results and aims of comprehensive SBCW pre-implementation study and long term assessment. A classification is proposed for methods only used for the preimplementation study (in blue), for the long term assessment (in green), or for both (in orange).

Some of the methods (specific to the pre-implementation study) presented here give results that are redundant (EM, ERT, GPR), and were run in our case study in order to compare them (that is not the purpose of this communication).

The authors emphasize the importance of the combination of each type of methods (water flow and spatialized soil types measurements - data fusion) in order to gain information about threedimensional water flow inside the system, and this before any SBCW building.

The knowledge of initial soil trace contaminants (organic and inorganic) is also a criterion regarding the potential operational risks (pollutants mobilization due to water infiltration) induced by soilbased SBCWs. Long term assessment of these parameters will allow us to evaluate the impact of SBCWs operation.

Design choice (trenches or meadows), footprint (in term of acceptable hydraulic loading rate), operation and placement of SBCWs inside the plot could be guided by results of these studies. However, as no validated approach exists so far, this remains a field of future research. 
Table 1. Classification and aims of methods for SBCWs pre-implementation study and efficiency assessment.

\begin{tabular}{|c|c|c|c|c|c|}
\hline & \multicolumn{2}{|c|}{ Method } & \multirow[b]{2}{*}{ Results } & \multirow[b]{2}{*}{ Involved processes } & \multirow[b]{2}{*}{ Goal } \\
\hline & $\begin{array}{c}\text { Spot } \\
\text { measurement }\end{array}$ & $\begin{array}{c}2 \mathrm{D} / 3 \mathrm{D} \\
\text { measurement }\end{array}$ & & & \\
\hline $\begin{array}{l}\text { Determination of } \\
\text { subsurface water } \\
\text { flow (qualitative) }\end{array}$ & Auger tests & Tracer tests & $\begin{array}{l}\text { Soil textures, infiltration } \\
\text { bulb }\end{array}$ & & Pre-implementation study: operational \\
\hline $\begin{array}{l}\text { Determination of } \\
\text { subsurface water } \\
\text { flow (quantitative) }\end{array}$ & $\begin{array}{l}\text { Piezometer; } \\
\text { Infiltrometer } \\
\text { tests; } \\
\text { FDR (water } \\
\text { content); } \\
\text { Tensiometers }\end{array}$ & $\begin{array}{l}\text { ERT; } \\
\text { GPR; } \\
\text { EM }\end{array}$ & $\begin{array}{l}\text { Infiltration capacity; } \\
\text { Water table (and } \\
\text { seasonal variation); } \\
\text { 3D mapping of the field }\end{array}$ & $\begin{array}{c}\text { Water flow } \\
\text { filtration and } \\
\text { bacterial activity } \\
\text { (Biomat formation) }\end{array}$ & $\begin{array}{l}\text { risks; SBCW design and placement; } \\
\text { Fate of the infiltrated water (catchment } \\
\text { scale) } \\
\text { Long term study: sustainability of the } \\
\text { infiltration capacity }\end{array}$ \\
\hline $\begin{array}{l}\text { Estimation of } \\
\text { subsurface water } \\
\text { quality } \\
\text { (quantitative) }\end{array}$ & $\begin{array}{l}\text { Porous cups } \\
\text { (subsurface } \\
\text { water quality } \\
\text { monitoring); } \\
\text { Pathogens; }\end{array}$ & - & $\begin{array}{l}\text { SBCWs efficiency (soil } \\
\text { component) for } \\
\text { pollutants removal }\end{array}$ & $\begin{array}{l}\text { Filtration, Bacterial } \\
\text { activity } \\
\text { (remediation) and } \\
\text { Adsorption- } \\
\text { desorption } \\
\text { (Leaching) }\end{array}$ & $\begin{array}{l}\text { Long term study: operational risks; } \\
\text { Validation of design choices }\end{array}$ \\
\hline $\begin{array}{l}\text { Soil pollution } \\
\text { parameters }\end{array}$ & $\begin{array}{l}\text { Soil quality } \\
\text { measurements } \\
\text { (trace } \\
\text { contaminants) }\end{array}$ & - & $\begin{array}{l}\text { Initial soil status; } \\
\text { Time-dependent } \\
\text { evolution }\end{array}$ & $\begin{array}{l}\text { Adsorption- } \\
\text { desorption } \\
\text { (Leaching) }\end{array}$ & $\begin{array}{l}\text { Middle term study: sustainability of the } \\
\text { SBCW }\end{array}$ \\
\hline
\end{tabular}

\section{CONCLUSION}

SBCWs such as meadows and ditches use soil for treated wastewater infiltration, thus questioning the fate of the infiltrated wastewater in term of quality and flow.

A detailed methodology for pre-implementation studies and long-term monitoring of these systems was presented. Special attention was given on processes occurring in SBCWs like pollutants removal/leaching and biomat formation. Perspectives of this work are to draw sustainable rules for SBCWs design and operation. 
We emphasize that, in the near future, SBCWs should be conceived as a kind of soil treatment units.

\section{ACKNOWLEDGMENTS}

The authors thank the Onema (the French National Agency for Water and Aquatic Ecosystems) for providing financial support to this work (BIOTRYTIS project, Bègles, France). We are also grateful to Bordeaux Métropole (33, France) for funding and support. 


\section{BIBLIOGRAPHY}

Ayaz, S.Ç. (2008). Post-treatment and reuse of tertiary treated wastewater by constructed wetlands. Desalination 226(249-255).

Binley, A., and Kemna, A. (2005). DC resistivity and induced polarization methods, in Rubin, Y., and Hubbard, S.S., Eds., Hydrogeophysics: Springer, pp.129-156.

Blin, E., Schuemacher, J., Paoletti, E., Jordi, J. (2014). Mesure d'efficacité des zones de rejet végétalisées : méthodes et résultats. [in french] Techniques Sciences et Méthodes 7-8(52-61).

Boutin (2014). Les Zones de Rejets Végétalisées : Eléments pour une meilleure conception. (in French) Downloadable at http://www.onema.fr/

AFNOR (2014). NF EN ISO 22282-5. Geotechnical investigation and testing - Geohydraulic testing — Part 5: Infiltrometer tests. ISSN 0335-3931.

AFNOR (1996). NF P94-157-2. Soils: investigation and testing. In situ pore pressure measurement. Part 2: pore pressure meter. ISSN 0335-3931.

Gette-Bouvarot, M., Mermillod-Blondin, F., Angulo-Jaramillo, R., Delolme, C., Lemoine, D., Lassabatere, L., Loizeau, S., Volatier, L. (2014). Coupling hydraulic and biological measurements highlights the key influence of algal biofilm on infiltration basin performance. Ecohydrology, 7 (3), pp. $950-964$

Kampf, R, van der Geest, H, Sala, L, Romani, A, Comas, J, Claassen, T, Gerbens, S, Neef, R, Menkveld, W. (2007). Biological filtration of treated waste water by Daphnia: an alternative for technical filtration, or an addition? Proceedings of the IWA 6th Conference on Wastewater Reclamation and Reuse for Sustainability, Antwerpen, October 2007.

Keller, A \& Auset, M. (2007). A review of visualization techniques of biocolloid transport processes at the pore scale under saturated and unsaturated conditions. Advances in Water Resources, 30(1392-1407).

Li, Y., Zhu, G., Ng, W.G., Tan, S.K. (2014). A review on removing pharmaceutical contaminants from wastewater by constructed wetlands: Design, performance and mechanism. Science of the Total Environment 468-469(908-932).

Ollivier, P., Surdyk, N., Azaroual, M., Besnard, K., Casanova, J., Rampnoux, N. (2013). Linking water quality changes to geochemical processes occurring in a reactive soil column during treated wastewater infiltration using a large-scale pilot experiment: Insights into Mn behavior. Chemical Geology 356(109-125).

Pagoto, C., Sergent, L., Serre, J., David, B. (2014). Les zones de rejet intermédiaires en assainissement : observations de terrain et comportement des polluants au sein de ces zones. [in french] Techniques Sciences et Méthodes 7-8(43-49).

Prost-Boucle S., Boutin. C. (2013). Etat des lieux national des Zones de Rejet Végétalisées (ZRV). (in French) Downloadable at http://www.onema.fr/IMG/pdf/2013_003.pdf. 58 pp. 
Siegrist (2014). Engineering Design of a Modern Soil Treatment Unit. Proceeding of the conference "Innovations in Soil-based Onsite Wastewater Treatment" April 7-8, 2014 Albuquerque, New Mexico.

Tzanakakis, V.A., Paranychianakis, N.V., Angelakis A.N. (2009). Nutrient removal and biomass production in land treatment systems receiving domestic effluent. Ecological Engineering 35(14851492).

Thullner, M. (2010). Comparison of bioclogging effects in saturated porous media within one- and two-dimensional flow systems. Ecological Engineering, 36(176-196).

Verlicchi, P., Zambello, E. (2014). How efficient are constructed wetlands in removing pharmaceuticals from untreated and treated urban wastewaters? A review. Science of the Total Environment 470-471(1281-1306). 